\title{
Service Innovation in Local Government: Analysis of Business Information Services in South Sulawesi Province, Indonesia
}

\author{
Badu Ahmad \\ Department of Public Administration, \\ Hasanuddin University, \\ Makassar South Sulawesi, Indonesia
}

Doi: $10.2478 / \mathrm{mjss}-2018-0063$

\section{Abstract}

\begin{abstract}
This article aimed to determine and analyze the implementation of innovation forms as well as the factors supporting and inhibiting the implementation of innovation in local government level. The research was conducted in three regions in South Sulawesi province: Bantaeng, East Luwu, and Makassar. The results of the research showed that the service innovation implemented in South Sulawesi was quite varied but has the same objective, i.e giving satisfactory service of business licenses for society. Bantaeng Regency Government implemented click innovation, changes employees' behavior without illegal charges and license delivery to applicant's home. Similarly, the East Luwu Regency government intensively innovated the management and one-day issuance of business license. While the Makassar Municipal Government focused more on weekend service innovation, delivering and picking up license documents. Supporting factors for service innovation in the three regions were regulation and commitment of the local governments while the inhibiting factors of innovation implementation were the limited fund and incompetent personnel in service duties.
\end{abstract}

Keywords: innovation, service performance, business license, local government, Indonesia

\section{Introduction}

The concept of innovation can be searched in contemporary State Administration levels around the world, i.e public choice that views public service delivery system as one of attention centers and a value to be maximized (Frederickson, 1984; Osborne and Gaebler, 1992; Berman, 1996; Brown et al., 2016). Therefore, organizational regulations can encourage innovation that can improve the performance of public services (Podger, 2015), and respond to citizen expectations and society needs (Mulgan and Albury, 2003), including leadership (Kim and Yoon, 2015; Munro, 2015). In addition, the communication and information technology-based service innovation is one of the tools used to actualize accountable and transparent services as a pillar of good governance (Ratminto and Winarsi 2005; Kim et al., 2005). This can't be separated from the dynamics of public sector organizations that require innovation in the form of implementation of new technologies, new methods in order to improve the results and quality of service products including the increase in local revenue. In turn, the terminology of government service is: the delivery of services by a government agency using its own employees, so efforts to improve the quality of services will become increasingly important.

In Indonesia, innovations in administration of regional governments especially related to services began to receive attention since the enactment of Law No. 32 of 2003 on Regional Government. Furthermore, Law No. 25 of 2009 on Public Service and Regulation of the Minister of Administrative and Bureaucratic Reform No. 30 of 2014 on Guidelines for Public Service 
Innovation. Prasojo, Kurniawan and Hasan (2004) in their study suggest that regions that successfully implement innovation on licensing services can improve the quality of service, and satisfaction and welfare of community. Empirically, there are several regions in Indonesia which become the best practice references in implementing innovation in public service such as; Jemrana Regency, Sragen Regency, Banyuwangi Regency, and Gorontalo which have institutional innovation through capacity building and the mindset change from bureaucratic to entrepreneur mindset. However, the results of previous research (Ahmad, 2014) have concluded that the performance of services provided by regional government bureaucracy shows: bureaucratic apparatus are showing themselves more as employers; service apparatus are more oriented to the status quo than the improvement of service; service apparatus are more concerned with procedures than substance; service apparatus are more selfish than community to be served; and they prefer to work conventionally rather than modernly and technology information-based. Yet the importance of improving public services is one of the benchmarks for legitimacy, credibility and capacity of governments (Osborne and Gaebler, 1992; Mulgan and Albury, 2003; Dwiyanto, 2006). We need to further analyze why those negative things happen? For this purpose, we selected locations of research on Indonesian local governments including Bantaeng Regency, East Luwu Regency, and Makassar Municipal in South Sulawesi province.

Based on the results of observation in the research locations, it was concluded that the implementation of innovation program of local government services in Bantaeng Regency, East Luwu Regency, and Makassar Municipal have given benefit in terms of efficiency and effectiveness of service for business license. However, problems related to the implementation of the service innovation for business license has not significantly influenced the improvement of community welfare and participation, so there is no guarantee that innovation can be maintain continuously. Based on the above description, this article will focus on research of innovation service for business license because entrepreneurs or investors complain about the performance of government services in business license arrangement in local government generally, especially in South Sulawesi Province.

Theoretically, the authors realize that if there is an improvement in the performance of business licensing services through innovation will have effects on the increase of investation climate or new businesses that will impact on the increase of local revenue, creation of new jobs, and welfare of people in regions. Quality service will be an added value, such as the satisfaction and willingness of people served to follow the applicable rules and regulations. The discussion in this article is divided into two parts. First, to describe and analyze the form and implementation of service innovation of business license in South Sulawesi. Second, to describe and analyze factors supporting and inhibiting the implementation of service innovation of business license in South Sulawesi.

\section{Methods}

The approach used was qualitative so that data collection techniques included observation, indepth interview, and focus group discussion. To obtain relevant and accurate data and information, informants registered were secretaries of the department, heads of the licensing service, heads of the investment field, service officers, and entrepreneurs/applicants who were proposing their business licenses. While the data analysis technique referred to the interactive model of Miles and Huberman (1994). The locations of this research included Bantaeng Regency, East Luwu Regency, and Makassar City.

\section{Results and Discussion}

\subsection{Innovation and Service in Perspective of Public Administration}

Henry (2012) explores the concept of innovation as one of the concepts of organizational theory that has ability to make changes, innovations, improvements, and adaptations, and it is very important in every form of organizational life. Changes in organizations are strongly influenced by 
three factors: organizational technology, organizational environment, and human interaction with technology and environment. In relation to the concept of innovation in organizational theory as one of public administration studies, the study of innovation in public administration began to evolve as the paradigm shift from the formalistic of Old Public Administration to New Public Management (NPM) following market mechanism and to more democratic New Public Service (NPS) (Denhardt and Denhardt, 2003; Osborne and Gaebler, 1992). Managers of public sector were encouraged to find new ways of working and innovation to gain maximum results or privatize governance functions.

Study of service innovation is inspired by the concept of reinventing government (Osborne and Gaebler, 1992) which seeks to transform the entrepreneurial spirit and performance into a mission- and result-oriented and competitive bureaucracy. In addition, NPM's contribution to the study of service innovation is critical because it is oriented to the leadership elements of professional work units, clear standards and performance measures, and emphasizes greater discipline and savings in the use of organizational resources, the use of information technology (IT) so that public institutions can work well and achieve its goals effectively and efficiently (Vigoda, 2003). NPS, similarly, positions citizens as the owner of government so that government together with community are both involved in serving and meeting the needs of community (Denhardt and Denhardt 2003). In essence, democratic services require innovative public administrators in the acceleration of public services. From here, the impetus to cultivate values of innovation in public organizations will emerge.

According to Albury (2005) characteristics of successful innovation are the creation and utilization of new processes, new products, new services and new delivery methods, resulting in significant improvements in efficiency, effectiveness, and quality. So we see that innovation is a new idea applied to initiate or improve a product or process, or service. Hartley (2005) argues that every innovation involves change, but not all change must involve new ideas or lead to significant improvements. Innovation in public sector management can also be defined as a creative idea, development of new policy designs and new operating standards generated by organizations addressed to public policy issues (UN, 2007). More complexly, the Australian National Audit Office (2009) formulates some of the prerequisites for successful innovation in the public sector as follows: (1) Leader of public sector is committed to encouraging the creation of innovation culture and dissemination of innovation; (2) Innovation shall be the organizational strategy and adequate resource; (3) Staff have the necessary skills, training, incentives and development opportunities; (4) Agencies encourage the emergence of innovation in internal environment and actively involve citizens and stakeholders to obtain ideas from external sources; (5) There is a deep understanding of core business, government policies and aspirations, the wider external environment and internal and external sources of information; (6) There are mechanisms to access and respond to emerging issues; (7) Agents always build ability or capacity of organization; (8) Innovation should be approved and appreciated. Based on various opinions on innovation it can be concluded that innovation related to: new knowledge, new ways, new objects, new technologies, and new discoveries that drive the increased efficiency and effectiveness of the work of the organization.

\subsection{Public Service Innovation in Empirical Perspective}

In Indonesian context, the importance of innovation in local governance has begun to become a concern since the shift of government system from centralization to decentralization. Formally juridical Law No. 22 of 1999 on Regional Government which was later renewed into Law No. 23 of 2014 became the normative basis for local governments to innovate in administering governance in region. Similarly, Government Regulation No. 6 of 2008 on Guidelines for Evaluation of Regional Government Administration, can be used as legal basis for regional government in improving its performance, one of the aspects of its assessment is new innovation in governance.

The emergence of successful program innovations undertaken by several local governments after wider decentralization was assessed by various groups and it has impact on the improvement of public services and community welfare. Decentralization is being undertaken so that development programs are in line with local conditions, gaining the support and involvement of local 
administrators and communities and integrating with the number of services needed to stimulate regional economic development. Various studies suggest that the success of local governments in innovating is seen as a model in measuring the success of local government (Irwan et al., 2012). The commitment of local government leaders is a factor that greatly influences the success of innovation. It also found that there are three components that have strong effects on improvement of local government performance, namely the level of social welfare, the quality of public services, and local competition. Doloreux (2004) in his research on local government innovation systems concluded that innovation activities are closely related to competence strategies, innovation processes, information sources utilization; innovation process related to work unit performance improvement; and there is a difference in performance for innovative work units. Similarly, Prasojo, Kurniawan and Hasan (2004) argued that the main obstacle to implement innovation of public services in Indonesia is the sectoral ego of the regional apparatus organization (known as OPD). This is in line with Thomas (2010) point of view who argued that innovation is largely determined by the commitment and capacity of local governments. While research has been done by R\&D of Central Java Province states that innovation program is most often created and implemented by regency and municipal government related to information technology implementation such as: Egovernment, website, LAN, SMS-Gateway. Meanwhile, Mirnasari (2013), states that the service quality is better because there are several innovations in the service unit, leadership commitment, clear vision, adequate human resources availability, and stakeholders' involvement. So far, innovations that have been made by local governments are institutional innovation, process innovation, and public service innovation.

In real implementation of innovations in several regions in Indonesia such as in Gorontalo, Maros, Sragen, Pinrang, and Jemrana, various dimensions of innovation capability also clearly affect the success of innovations implemented by those regions. Therefore, an understanding of the innovation capability will help government bureaucracy to innovate, but nevertheless innovation capability will not automatically produce innovation. Innovation in public services will occur when innovation capability is placed in three domains, that are drivers and enablers of local government innovation capability, including sustainable development, e-government, and new product development. In Indonesia, efforts to establish public service standards in order to improve the quality of public services are shown by the publication of various ministerial policies until today.

\subsection{Forms of Service Innovation in Business License in Three Regions}

Based on the research results, some forms of implemented innovation were found as the following.

\subsubsection{Bantaeng Regency}

Click Innovation. This innovation is related to the granting of principle permit and location permit directly signed by the Regent with a validity period of 6 (six) months. The innovation is a contribution of new service innovation typology and policy innovation as stated by Halvorsen (2005) which is implemented to encourage the acceleration of infrastructure development and facilities of invested business. Click Service for investors also provides permit arrangement i.e location, building, environment, company registration, business location permit, business and industry license. After an investor obtains the principle permit from the Regent, the next step is to manage the operational permits signed by the Head of the Capital Investment Office and PTSP of Bantaeng Regency.

No-Illegal-Charge Service. To maintain the integrity of clean and responsible licensing officers, the regent and the head of department affirms to all officers to "work with all your heart", not to receive any giving from applicants. The implementation of this innovation is a contribution from the innovation of work systems and the mental changes of employees to maintain the integrity and professionalism of civil state apparatus. If there is any illegal charge imposed by a service personnel, then he/she will be given a sanction, and there will be a doubled refund for service operational cost to applicant when illegal charge is proven.

Delivery of License Documents. If two days after the signing of business license is not picked 
up by applicant, service officer shall deliver it directly to applicant. The innovation is the implementation of new service innovation, innovation of interactive policy between government and society. This is done as a form of local government commitment in creating excellent service and maintaining harmonious relationship and communication between government and society.

One Stop Integrated Services. Public utilizes automated services in extending permits a month before due date. The main tool that supports One Stop Integrated Services is computerbased information technology. Although the electronic-based online service is not maximized, applicant can track the development of business license through the website of www.bantaengkab.go.id.

Technopreneurship camp. The government conducts training for entrepreneurs in utilizing technology to improve productivity through the implementation of new technologies, especially seed industry technology that continues to evolve from time to time. This innovation is a new service after the issuance of fishery business permit.

All forms of service innovation mentioned above maximize One Stop Integrated Services (known as PTSP) in issuing all forms of licensing related to business. Certainty of time and accuracy of service in this PTSP has made people feel very helpful in licensing arrangement for their businesses. While the service process is more focused on improving quality of service based on consistent operational procedure standard (SOP), computerized data processing, online registration, SMS Gateway, payment via Bank, comfortable and conducive service room.

The Regent, Nurdin Abdullah, made a policy innovation which authorized the Head of PTSP Department to sign all types of business licenses except the principle permit which is still signed by the regent. Such authority is proven to encourage the acceleration of services to the interested society. As a follow-up of these policy innovations, work system innovation that supports the achievement of service excellence mission is needed. In addition to the parallel licensing policy innovation, i.e conducted licensing administration given to entrepreneurs is simultaneously covering more than one type of permit, which is processed in an integrated and concurrent way.

\subsubsection{Luwu Timur Regency}

In Luwu Timur Regency, the Regent made the following innovations: first, implementing innovation of information technology-based work processes to create an easy, transparent and accountable licensing service system; second, implementing employee mental innovation through education and training of electronic-based services so that employees have capabilities and skills, honesty, and loyalty in carrying out their tasks; third, implementing new service innovation through the development of zero complain service as a manifestation of apparatus professionalism in serving society; fourth, implementing innovation work system without scalpers that emphasize the motto "Serving You, Build Together", one of the services performed is delivery of service products if the service is not punctual; fifth, "Free-of-Charge Licensing" as part of new service innovations that facilitates the process of obtaining licences and permits for Micro, Small and Medium Enterprises (MSMEs) with one day permit service completion; and the last is the implementation of One Stop Integrated Services policy.

One of the most influential policy innovations is free-of-charge licensing service. This innovation helps small businesses to accelerate their growth. The ease of obtaining licenses for MSMEs entrepreneurs is based on Presidential Regulation No. 94 of 2014 on Licensing for micro and small and medium enterprises and Minister of Home Affairs Regulation No. 83 of 2014 on guidelines for granting micro and small and medium business licenses. In accordance with these provisions, the granting of licenses for MSMEs entrepreneurs is delegated to heads of sub-regency and urban village. Besides free-of-charge, the procedure is easy. In fact, each sub-regency has a team of assistants who visit to MSMEs entrepreneurs to request the necessary administrative requirements.

\subsubsection{Makassar Municipal}

Innovation performed by Makassar municipal government is to provide the best service to 
community for example delivering business license service with ease, transparency and according to standard operating procedure (SOP). Local government made changes and improvements for licensing service system and gave attention to facilities and infrastructure in service offices, innovation of special parking for community who are applying their business licenses. The innovation program launched in May 2017 is innovation of free home delivery as part of a new service innovation so that people can be more helpful by not coming back and forth to pick up their license files in the office. The results of interviews from entrepreneurs can be concluded that home delivery innovation is very efficient, effective, and economical. This is in line with the new service innovation typology and service system by Halvorsen (2005) who stated that every innovation expects the occurence of service excellence. Public are very respectful of this innovation so that they want the service innovation of home delivery to be contained in local regulations to ensure their sustainability.

Local government innovation on free delivery service triggered all sub-regencied to prepare motorcycles for the service in all sub-regency offices. These motorcycles are designed by putting a box on the back to save applicants' files. Each motorcycle has phone number and email of a village office to utilize the service facilities. The motorcycles have symbol of "motor lorongta" to pick up and deliver administration as part of the service. Heads of sub-regencies conducted socialization about the procedure of telephone and e-mail usage which is received directly by operators to be followed up by officers. To maximize the innovation of document delivery service, the local government provides the Mini Wall Room as an innovation to monitor activities in each sub-regency in order to control every service provided to community through the installed monitoring cameras.

In addition to the above innovations, regional government also create comfortable service room with an electronic-based queuing system. Employees are responsive and full of attention to every citizen who needs service so there is an effective reciprocal communication. To provide certainty of business license completion, each applicant is asked for phone number to communicate related to progress of the completion. The Municipal Government of Makassar has a commitment to accelerate licensing services in accordance with the Decree of the Mayor of Makassar on the Acceleration of Licensing Service Implementation. To fully implement the substance of the decision, the Decision Letter On Weekend Service was issued. Innovation policy in the form of weekend service is conducted every Saturday. The purpose of weekend service is to provide more opportunities, simplicity, and acceleration of licensing arrangements.

\subsection{Factors Supporting and Inhibiting Business License Services in Three Regions}

Based on the results of field research, it was found that the factors supporting implementation of innovation in Bantaeng Regency include: the qualified human resources who have bachelor degree so that in general employees have potential to find and implement innovations that can improve the quality of services; utilizing online media and information technology to accelerate services to the community; the Regent delegating his authority to the Head of Department to sign licensing letters in order to facilitate and accelerate the licensing arrangements; and comfortable and conducive service room for personnel and applicants who are waiting for the service process. While the factors inhibiting the implementation of license service innovation are the less-optimal use of one stop integrated service. This is because it has not integrated the technical units which are directly related to business license service required by community. Other inhibiting factors include: too high intensity of employee rotation so new employees have to undergo excellent service and use of information technology trainings that support the administration of online services; limited operational budget so that the implementation of service innovation is less than maximum; centralized authority caused so many pending work completion; and the limited number of personnel who conduct supervision and control of licensing arrangements.

Similarly, the results of research in East Luwu Regency showed that there are several supporting factors, among others: the availability of licensing service information system on the website of kppt.luwutimurkab.go.id; and there is a local government regulation on delegation of authority from the Regent to the Head of Departmenet. This regent's regulation is a policy innovation that supports the success of public service innovation. This is in line with the opinion of 
Mulgan and Albury (2003), stated that regulation is a major supporting factor for the implementation of an innovation. Regulation can regulate the behavior and governance of quality services. While the inhibiting factors for implementation of business license services are less-optimal of one-door integrated service (PTSP) because it has not integrated technical officers from related organizations into the same building or spatial of licensing service. The results of the interviews showed that technical officers are more comfortable working in their respective organizations according to their main tasks and functions. Partial working method like this is inefficient and ineffective because applicant should back and forth between one office to another office. This is in line with local observers' view stated that sectoral-ego is a major obstacle to uniting work units into a more productive work system (Prasojo et al., 2004). Another inhibiting factor is the limited apparatus resources resulting in multiple works done by apparatus that inhibit the work completion, which also the main cause of multiple positions. Finally, the limited operational budget supporting the implementation of licensing service innovation.

Meanwhile, in Makassar Municipal, the supporting factors for the implementation of business licensing services include: the availability of regulations enable innovation to be done well; the availability of conducive and comfortable service rooms for employees and applicants who are waiting for the service process; intensive training programs to develop technical, personality and ethics skills for licensing managers to create high quality apparatus; and the availability of electronic data processing and licensing documents. While the inhibiting factors for the implementation of licensing service innovation in Makassar Municipal, among others: limited operational budget so that there are some socialization activities of excellent service has not been performed; the utilization of technology in the service coordination function is not adequate so it can inhibit the excellent service delivery; recruitment of under-qualified contract workers so that team performance in service process is so low; the number of service employees is not balanced with the number of applicants causing service process takes long time and not in accordance with the standard of service; bureaucratic system that has not implemented standard operational procedures maximally so it is difficult to measure the performance of services.

\section{Conclusion}

Various innovations made by local governments in three regions of South Sulawesi are appropriate means to actualize the excellent public service system. The first is the easy service i.e incomplicated procedure which is in accordance with operational standards and service mechanisms that have been set. Second is the low cost service where the cost can be afforded by all levels of society in accordance with the prevailing charges. The third is fast service, i.e the completion time does not exceed the maximum stipulated time limit. And the last is transparency, i.e service process can be known by all levels of society regarding service procedures, service requirements, completion time and service charges.

Innovations developed by the three local governments greatly assisted the acceleration of services including employees' mental innovation that has effect on the integrity of truth and beliefs so that no illegal charges were found in the licensing service process. In addition, local government innovations through an integrated system, the principle of one stop integrated service, can run well as the form of optimizing government roles in creating good governance at the local level.

To ensure continuous service performance, it is recommended for local governments to undertake recruitment of employees who have competence in accordance with the field of service duties and functions, while the existing employees need to be involved in education and training related to licensing services. Other resources need to be provided to support the sustainability of innovation is the availability of adequate budget according to annual budget proposals of each local government organization. To actualize the service innovation that can encourage the improvement of quality and performance of public services, values that must be developed are commitment, trust and loyalty to organization's goals by always doing innovation as the best effort in carrying out services with responsibility; integrity, consistent basic and mental attitudes in supporting noble values, truth and beliefs; and by working with sincerity and earnestness. 


\section{Acknowledgments}

I would like to thank the Ministry of Research, Technology and Higher Education through its PUPT Grant and LP2M of Hasanuddin University for funding in 2017. Thanks to Baharuddin and Adnan Nasution for their helpful and challenging comments.

\section{References}

Ahmad, B. (2014). Manajemen pelayanan umum. Jakarta: UT-Press.

Albury, D. (2005). Fostering innovation in public service. Publik Money and Management 25 (1), 51-56.

Podger, A. (2015). Innovation in the public sector: beyond the rhetoric to a genuine 'learning culture'. In J. Wanna, HA. Lee, and S. Yates (Eds.) Managing under austerity, delivering under pressure (pp. 119-130). Canberra: ANU Press.

Australian National Audit Office, 2009. Innovation in the public sector: enabling better performance, driving new directions, better practice guide. Canberra: Australian National Audit Office.

Denhardt, J. V. \& Denhardt, R. B. (2003). The new public service: serving, not steering. New York: M.E. Sharpe.

Doloreux, D. (2004). Regional innovation system in canada: a comparative study. Regional Studies 38 (5), 481 494.

Dwiyanto, A. (2006). Mewujudkan good governance melalui pelayanan publik. Yogyakarta: Gajah Mada University Press.

Berman, E. M. 1996. Innovation in Local Government: Past, Present, Future. International Journal of Public Administration 19 (7), pp. 1027-1036.

Frederickson, H. G. (1980). New public administration. Alabama: University Alabama Press.

Halvorsen, T. (2005). On the differences between public and private sector innovation. Oslo: Publin Report.

Hartley, J. (2005). Innovation in governance and public services: past and present. Public Money and Management 25 (1), 27-34.

Henry, N. (2012). Public administration and public affairs, $\left(12^{\text {th }}\right.$ edition). London: Routledge.

Irwan, N., Sjamsuddin, S., Supriyono, S., \& Hakim, B. (2012). Dynamic Innovation of Local Government in Indonesia. Journal of Basic and Applied Scientific Research 2 (5), 5052-5057.

Munro, J. (2015). Accelerating innovation in local government. Public Money and Management 35 (3), 219-226.

Miles, M. B. \& Huberman, A. M. (1994). Qualitative data analysis: an expanded sourcebook, ( ${ }^{\text {nd }}$ edition). London: Sage.

Mulgan, G. \& Albury, D. (2003). Innovation in the public sector. Working Paper Version 1.9. London: Cabinet Office Strategy Unit.

Osborne, D. \& Gaebler, T. (1992). Reiventing Government: How the Entrepreneurial Spirit is Transforming the Public Sector. Massachusetts: A Willian Patrick Book.

Prasojo, E., Kurniawan, T., \& Hasan, A. (2004). Peran kepemimpinan dalam program inovasi daerah: studi kasus kabupaten jemrana. Jurnal IImu Administrasi dan Organisasi: Bisnis dan Birokrasi 12 (3), 77-189.

Ratminto \& Winarsi, A. S. (2005). Manajemen pelayanan: pengembangan model konseptual, penerapan citizens charter dan standar pelayanan minimal. Yogyakarta: Pustaka Pelajar.

Mirnasari, R. M. (2013). Inovasi pelayanan publik uptd terminal purabaya bungurasih. Kebijakan dan Manajemen Publik 1 (1), 71-84.

Kim, S. \& Yoon, G (2015). An innovation-driven culture in local government. Public Personnel Management 44 (2), 147-168.

Thomas, H. (2010). Tinjauan daya inovasi pemerintah daerah dalam pelaksanaan desentralisasi di provinsi kalimatan timur. Jurnal Burneo Administrasi 6 (3), 2161-2174.

Brown, T. L., Potoski, M. \& Slyke, D. M. V. (2016). The impact of transaction costs on the use of mixed service delivery by local governments. Journal of Strategic Contracting and Negotiation 1 (4), 239-267.

United Nations (UN) (2007). Innovation in government in the middle east, north africa and western balkan: making government work better in mediterranian region. New York: United Nations Publications.

Vigoda, E. (2003). New public management. In J. Rabin (Ed.) Encyclopedia of public administration and public policy. New York: Marcel Dekker.

Kim, P. S., Halligan, J., Cho, N., Oh, C. H. \& Eikenberry, A. M. (2005). Toward participatory and transparent governance: report on the sixth global forum on reinventing government. Public Administration Review 65 (6), 646-654. 